\title{
第15回日本肝臓学会総会抄録（2）
}

\section{シンポジウムII: 肝不全の代謝動態とその対策} \\ 司会 高橋善弥太 (吱皋大学第 1 内科) \\ 菅原 克彦 (東京大学第 1 外科)

\section{1. 劇症肝炎における肝再生因子の動態と グルカゴン-インシュリン療法} \\ 沖田極松田 彰史 \\ （山口大学医学部第 1 内科）
}

期日：昭和54年 6 月30日

会場：毎日大阪会館大ホール

劇症肝炎の治療の根本は肝再生力の助長にあるといえ る. 著者らはこの急性肝不全の治療にクルカコンンーイ シュリン療法”を試み，救命率の向上を確認しているが， このクルカコンとインシュリンは向肝性因子 (hepatotrophic factor) として, 肝再生と密接な関係を有すると 考えられている.そこで，急性肝不全時における肝再生 の生物学的指標が，その経過に伴ってどのよらに変化し ていくのか，といらことを明らかにすることは，その対 策を考える上て栖めて重要である。

今回，実験動物に作製した㓺症肝炎モデルを用いて以 下の検剖を加えた。

(1) 実験モデル (Fig. 1)

a) 死亡率に与えるグルカコンンーインシュリン (「G-1」) の效果：ウィスター系雄性ラット(20時間絶食)に2,000 $\mathrm{mg} / \mathrm{kg}$ - 体重の D-galactosamine ・ HCl 塩を生食に溶解 し，PH 補正後，i.p. にて投与した. 30匹のラットを3 群に分け，注射後24時間目に「G-I」を Fig. 1に示した 量を投与した「G-I」群， $1 \mathrm{mg} / \mathrm{kg}$ 体重の「G」を投与し た「G」群，および， $1 \mathrm{ml}$ の生食を投与した「control」 群について，D-galactosamine 投与後72時間目までの死 亡率を求めた．その結果，「G-I」群では 2/10の死亡例 を認め「G」群とは8/10，「control」群では 4/10であ った。

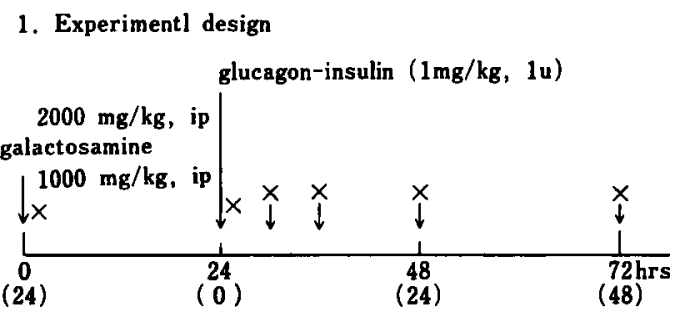

2. Change of markers for regeneration
a. AFP in tissue
b. c-AMP, c-GMP level in tissue
c. DNA synthesis

Fig. 1 method

b) 肝再生因子を検討するための劇症肝炎モデル：先 に著者らは D-galactosamine ・ $\mathrm{HCl}$ 塩の投与による劇症 肝炎モデル作製について報告したが，今回もこの既報の 方法 ${ }^{2)}$ に従い， $1,000 \mathrm{mg} / \mathrm{kg}$. 体重の D-galactosamine を i.p. で投与し，24時間目に，前述の量の「G-I」を投与 した「G-I」群，「G」群，「control」群を作製し，Fig. にに示した「メ」印の時間にラットを屠殺し，その形態 学的変化の差巽を調ぺた. その結果は Table 1に一括し て示した。

\section{（2）肝再生因子の模討}

a)「G-I」の障害肝における DNA 合成能に与える影 
Table 1. Association with regeneration or repair and AFP in the damaged liver after treatment with glucagon insulin

\begin{tabular}{|c|c|c|c|c|}
\hline & $\begin{array}{l}\text { Histology } \\
\text { necrasis }\end{array}$ & $\begin{array}{l}\text { Locali- } \\
\text { zation } \\
\text { of AFP }\end{array}$ & $\begin{array}{l}\text { Labelling } \\
\text { Index } \%\end{array}$ \\
\hline \multicolumn{2}{|c|}{$\begin{array}{l}24 \text { hrs after } \\
\text { Gal injection }\end{array}$} & 3 & - & ND \\
\hline \multirow{3}{*}{ 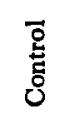 } & $6^{\circ}(30)$ & 3 & ND & ND \\
\hline & $12^{\circ}(36)$ & 2 & + & ND \\
\hline & $24^{\circ}(48)$ & $1-0$ & ND & 3.0 \\
\hline \multirow{3}{*}{ 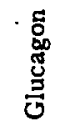 } & $6^{\circ}(30)$ & 3 & ND & ND \\
\hline & $12^{\circ}(36)$ & 1 & \pm & ND \\
\hline & $24^{\circ}(48)$ & 1 & ND & 2.6 \\
\hline \multirow{3}{*}{ 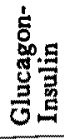 } & $6^{\circ}(30)$ & 2 & + & ND \\
\hline & $12^{\circ}(36)$ & 1 & $H$ & ND \\
\hline & $24^{\circ}(48)$ & 0 & + & 6.8 \\
\hline
\end{tabular}

3 : massive

2 : submassive

1 : focal

0 : normal

響：「G-I」群，「G」群，「control」群について，各 各の加療をおこなった後，24時間目のS 期の細胞を検討

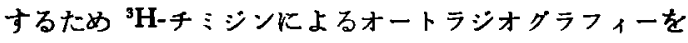
おこなった。なお，本法の施行にあたって $0.5 \mu \mathrm{Ci} の$ $\left[6-{ }^{3} \mathrm{H}\right]$ チミシン $(5 \mathrm{Ci} / \mathrm{mmol})$ を屠殺前30分前に投与 した.その結果は Table 1 に示した通りで，「G-I」群 において有意に S 期の細胞が増加していた。

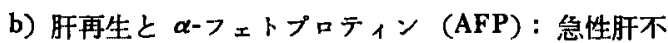
全症例の加䪭にあだって，その経過中に AFP の一通性 上畀がみられた場合，その予後の良いことは既に報告さ

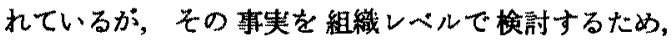
蛍光抗体法を用い，「G-I」群，「G」群，「control」 群で，その産生細胞を検討した. Table 1に示したよら に,「G-I」群では経時的に AFP 産生細胞は增加し, 「G-I」投与後12時間で，陽性細胞は最大であった。

c) 肝再生と cyclic AMP 及び cyclic GMP : ラット 肝部分切除後の残存肝細胞内では RNA, DNA 合成の前 時期に cyclic AMP の上异が認められる事 ${ }^{3)}$ 中, 脺内分 泌を抑制したラット残存肝では cyclic AMP の変化は 認められず，それに呼応して再生反応る認められないと いった報告"が既にみられるか，著者らむ，この劇症肝 炎モデルを用い，再生とこれら nucleotide の関係を検 討した。その結果は Fig. 2 に示した通りで，3群のい
SEVERE HEPATITIS BEARING RAT

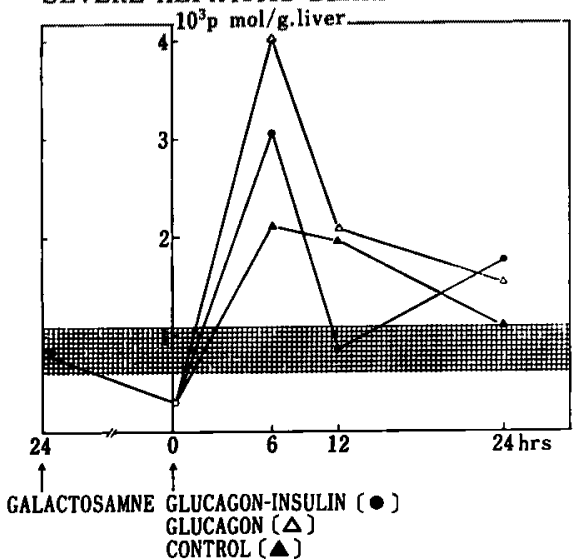

Fig. 2 Change of tissue c-AMP level after treatment with glucagon-insulin in d-galactosamine induced

ずれも6時間目に cyclic AMP 值の最大を示したが， $「 \mathrm{G} 」$ 群が「G-I」群より高値を示した。「G-I」群では 2 峰性と考えられる cyclic AMP の変動をみたが，こ の意義については現在のところ明らかではない. cyclic GMP についても，同様の検索をおこなったが，陰陽説 が唱えられているように, cyclic AMP とは相反する変 化を示した. Fig. 2に示した成績は各群とす 3 匹ずっ 3 回の実験をおこない，その平均値をブロットしたすので ある. 先にる述べたよらに，グルカゴンとインシュリン は門脈を経由する向肝性因子であるが，これらの膵ホル モンの門脈を介しての障害肝に与える影響を次に検討 してみた，未だ完全な检討を扰こなってはいないが、 D-galactosamine（1,000 $\mathrm{mg} / \mathrm{kg})$ 投与後24時間目に，工 一テル麻酷下に開腹 L $1 \mathrm{mg} / \mathrm{kg}$. 体重の「G」を投与し たところ，その cyclic AMP 唀導に与える影辢は，30 分以内という極めて 短時間内に 観察された．「G-I」群 については目下検索中であるが，この成績は「G-I」療 法を程門脈的におこならことの有用性を示唆するものと 考えている.

以上の成嚗から，磼かに「G」単独投与は「G-I」投 与に比べ, cyclic AMP の誘導は大きいが, 死亡率や肝 組織の修復という観点からみれば「G-I」群，「control」 群に劣るといら結果が得られた.グルカゴンとインン リンといら 全く作用の相反する膆ホルモンの 同時投与 が，どのよらな作用機序によって，再生を促進するか は不明で, Bucher ら"が「共役的效果」とした域を出る 
ことはできなかったが，著者らは「生化学的病理（biochemical pathology)」という観点加 5 ，急性肝不全時 の再生反応を示す生物学的指標を明らかにし「沗-I」投 与か，それを促進させることを明らかれした。

索引用語：グルカゴンーインシュリン療法, 朋再生,

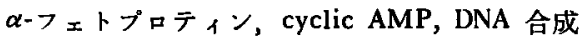

\section{文献}

1）沖田 極他：肝疾患治療薬の作用に関する基礎 的研究 (3) glucagon-insulin 療法に上る急性, 慢性肝不全の治療. 肝臟，19：854，1978.

2）沖田 極他：肝疾患治療薬の作用に関する基礎 的研究 (2) 重症肝炎の治療を目的とした glucagon-insulin 療法の基磷的研究. 肝臓，19：
$848,1978$.

3) Macmanus, J.P. et al.: Increase in rat liver cyclic AMP concentrations prior to the initiation of DNA synthesis following partial hepatectomy or hormone infusion. Biochem. Biophys. Res. Comm., 49: 1201, 1972.

4) 营原克彦他 : 肝再生時の肝，脺相関に関する基 礎的研究. 日外誌，78:989，1977.

5) Bucher, N.I.R. \& Swaffield, M.N.: Regulation of hepatic regeneration in rats by synergistic action of insulin and glucagon. Proc. Natl. Acad. Sci. USA., 72: 1157, 1975.

\title{
2. 肝不全のエネルギー代謝動態
} 一散乱反射スペクルト解析からみたその対策一

\author{
佐藤 信紘 七里 元亮鎌田 武信 \\ (大阪大学第 1 内科)
}

教室で過去 5 年間に扱った急性〜亜急性肝不全症例は 13例であった．救命例は 2 名であり，その治療法はステ ロイド 1 例，交换輸血 1 例であった。. 死亡例の主治療法 は種々で，ステロイド，交換输血（total body washout を含む)，charcoal を含む血夜透析，グルカゴンーイン シュリン原法，一ヘリンさらに Hep II etc のדミ， 酸榆液であった，死亡例の肝は何れる massive necrosis で，㹬とんど肝再生像がみられなかっだ、そこでこれら 治療法について再検討を加えると共に，䀒再生・増殖に ついて基礎的検討を行なった結果，細胞堌殖の初期には 高濃度のクルンースを必要とし，增殖中期以降には好気 的エネルギー代謝が主役を担らことが明らかとなった。 さらに，慢性肝障害の血流とエネルギー代謝動態を，in vivo の反射スペクトル解析 ${ }^{1,2)}$ で調へ，慢性肝障害の病 態代謝について検討した。

\section{方 法}

SD 系120〜200g の雄性ラットを用い，再生肝には， 肝切除 $(67 \%)$ 後 5 〜 10時間毎に反射スペクトル分析, 呼吸酵素の分光分析， $\mathrm{O}_{2}$ 電極による $\mathrm{O}_{2}$-uptake を調へ た。障害肝の再生の娭索化纴 Acetaminophen $2.5 \mathrm{~g} / \mathrm{kg}$,
$\mathrm{CCl}_{11} \sim 2.5 \mathrm{~m} l / \mathrm{kg}$ を切除前 $24 \sim 28 \mathrm{hr}$ に処置し，切除時の スペクトル分析 etc をコントロールと比校した.

践器反射スペクトル分析は既述の装卧尚,2) 用い，6 $\mathrm{mm} \phi$ 石英光学線維を肝に密着せしめ行なった１つの スペクトル $(185 \mathrm{~nm})$ のとりこみ時間は0.16〜0.32秒で あっだ。

慢性肝障害は24例で，肝硬变13例，慢性肝炎11例であ

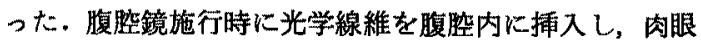
観察しながらスペクトル測定を行なった。

\section{結 果}

（1） 再生時の $\mathrm{O}_{2}$-uptake を経時的にみると Fig. 1 に示寸如く, 肝切除後早期には衍前に比し低下を示し, その後36〜48hrs 目に術前より增加を示した（130〜150 \%).このとき肝の呼吸醉素も同様の 経過をたどり，肝 切除後一時低值を示し，その後増加，48hr 目には切除 前の1.5倍となった. 呼吸酵素の上昇は $1 \mathrm{~W}$ 以上持経し, 10〜20日目で切除前値に復した。

術直後のATP レベルは切除後 5〜10時間では術前と かわらずまた肝を約10秒 anoxic 保って，後測定し た ATP レペルは，有意に低值を示すことから ATP の 


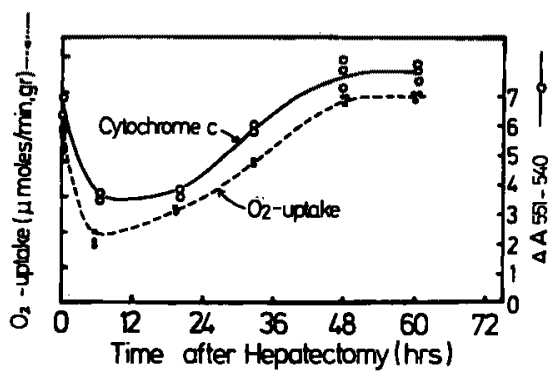

Fig. 1 Hepatic $\mathrm{O}_{2}$ uptake and cytochrome c concentration after partial hepatectomy

利用六進が示された。

この結果は, 術直後の再生初期には低呼吸, 低ミトコ ンドリア機能状熊であり，主として解糖手のエネルギー 座生が主役を演じ，高濃度のダルコースの供給が重要と 考えられた。 また。このグルコースの然烧にはインシェ リンが重要であると考えられた.

（2）しかし：トトンドリアの蛋白合成阻憲剤 ethidium bromidle をハムスターの fibroblast の細胞培 養液に添加すると, cell は12〜24hrs 後增殖が停止し, 呼吸酵素の 低下と共に 6〜8日で死減した。同様に， Acetaminophen, $\mathrm{CCl}_{4}$ を前処置し, 䠞器反射スペクト ル解析で, 局所の肝血流と呼吸能の低下が明らかとなっ た状態で肝切除を行ならとタルュース注入にも拘らず, 大半は1〜2 日後死亡した.これは好気的エネルギー代 謝の発現が肝再生に重要であることを示していた。また ミトコンドリアの発達にはインシュリンの他に, $\mathrm{T}_{3}, \mathrm{~T}$ 、 が呼吸能，呼吸醅素量を著しく上昇せしめるので重要で あると考えられた。以上，肝再生には全期を通し $\mathrm{O}_{2} か ゙$ 必要であるが，とくに初期は門脈血中に高濃度のグルコ 一スが必要ですり，中期以降には好気的ェネルギー代謝 の発達が重要と考えられた。さらに機能を持った成熟肝 細胞の增殖が完了するまでは，交換輸血，血液透析，血 中 A. A. バターンの是正など, 肝補助が重要と考えら れた (Fig. 2).

（3）慢性肝障害患者肝の in vivo 血流とエネルギー 代謝動態を眬器反射スペクトル解析した結果, 次のこと が判明した。

a) 硬変肝では局所の血流量が減少し，b）局所のオキ シヘモグロビン量の減少る著しく，肝はヒボキシックで あった (Fig. 3). c) 大部分の代償性肝硬変では $\mathrm{O}_{2}$ 摂 取率を高め $\mathrm{O}_{2}$ 消費を保っていた。d) しかし，著明な 血流低下例では局所の $\mathrm{O}_{2}$ 消費速度怔低下し，箸しい

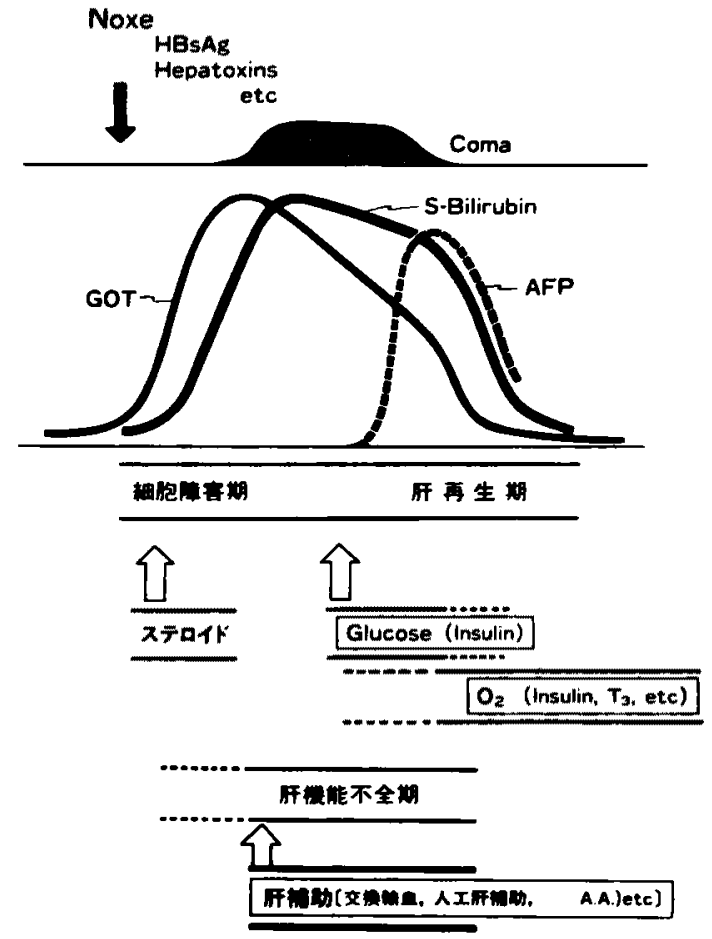

Fig. 2 Approach for treatments of the acute hepatic cell necrosis, hepatic functional failure and for hepatocyte regeneration.

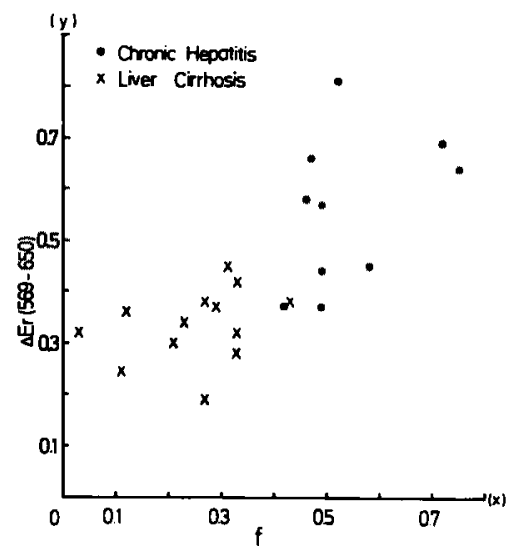

Fig. 3 Relation between the hepatic blood volume and the degree of hypoxia in human livers in situ.

肝機能異常を示した。e）この様な肝でも，生検後 $\mathrm{O}_{2}$ 電極で呼吸能を調べると，呼吸基啠添加に上り活発な呼 吸を示した，徒って in vivo の呼吸の低下は血流の低 

$96: 1308$
訮
20 卷12昘 (1979)

下ないしは呼吸基筫の低下゙など細胞摆境の異常に基つく と考光られた。

これらの結果から，慢性肝障害の肝機能の維持向上に は血流の增加と呼吸基質（基剤のグルコース）の供給を 図ることが最も重要であり，また血流の増加が期街でき ない場合には，肝がヒポキシックであり，かつ朋細胞自 身の呼吸能が維持されていることより，肝の $\mathrm{O}_{2}$ 需要を 極力減らせる工尖，すなわち $\mathrm{NH}_{3}$ やアミ，酸処理をで
きるだき避け，グルコースの肝内利用を図ることが肝要 と考えられる。

索引用語：朋不全, エネルギー代謝, スベクトル解析, 肝再生, 肝血流.

\section{文献}

1) Sato, N. et al.: Gastroenterol., 76: 814, 1979.

2) Sato, N. et al.: In Cytochrome Oxidase ( $T$. King, ed) Elsevier, pp. 319, 1979.

\title{
3. 肝性昏睡に対するアミノ酸 $(\mathbf{M O - 8 0})$ 療法の効果を
}

\section{左右する因子に関する臨床的・実験的検討}

\author{
佐藤 俊一 遊佐不三雄鈴木一幸 \\ (岩手医科大学第 1 内科)
}

\section{I. 目 的}

我々は Fischer $ら^{1,2)}$ が訮性昏睡に 有効と報告したア ミノ酸溶液（FO-80）と同様の組成の MO-80を作成し， その治療効果が極めて優れていることを報告しだ)。し かし MO-80㞠法では血漿遊離】ミノ酸 (PFAA) で $(\mathrm{Val}+\mathrm{Leu}+\mathrm{Ile}) /(\mathrm{Phe}+\mathrm{Tyr})$ モル比(BCAA/AAA モル 比）の改善をみるむ，昏睡の改善をみない症例が存在す ることから，MO-80療法の効果を左右する因子を主とし て生化学的レベルで臨床的・実験的に検討した。

\section{I. 方 法}

対象は肝硬变に上る皆睡15例，エック瘦犬12頭であ る. 臨床例は MO-80 1,000m $l$ を $10 \%$ glucose $1,000 \mathrm{~m} l$ とともに約 10 時間 1 回点滴投与例と，MO- $80500 \mathrm{ml}$ を $10 \%$ glucose $500 \mathrm{ml}$ ととすに連日 1 週間投与例である. MO-80療法で㚛睡度ならびに脳波の改善をみたものを 改善例，意識改善をみないか，少しみても脳波上不变の ものを不变例とした．動物実験は，MO-80 $200 \mathrm{ml}$ 単独 30分間点滴投与群と，MO-80 $300 \mathrm{ml}$ を $10 \%$ glucose $300 \mathrm{ml}$ とともに約 6 時間点滴投与群である，さらに筋 弛緩剤(サクシン)，インスリン，グルカゴンの諸検査 值に及ぼす影䇾も観察した。

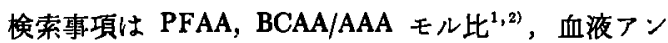
$€=ア\left(B-N_{3}\right)$ ，血清尿素窒素 (SUN)，血嶈遊離脂肪 酸 (PFFA) ${ }^{4}$ ，血糖 (BS)，血中インスリン・ダルカコ
ン (IRI ・ IRG) および IRI/IRG モル比方である。

III. 成 績

1. 臨床成精

1）ＭO-80 10時間投与例：10例中改善 7 例, 不変 3 例であった．改善 7 例中 5 例は治療前昏睡度は I，II 度， 2 例が III，IV度で，不変 3 例ではすべてIV度であっ た.

MO-8010時間投与時の諸検査值の変動を検討した． BCAA/AAA モル比 (Fig. 1) は改善例, 不变例とる MO-80投与開始 6 時間で最も高值を示し，すへて正常值 内に改善し，24時間後には投与前值にもどった。 PFAA のらち特に Met は不変例では改善例に比し経過中増加 の傾向を示した．B-NH, (Fig. 1) は不変例ではMO-80 投与前に高値を示し, 経過中常に改善例の約 2 倍の高値 を示した. SUN (Fig. 1) は改善例では経過中平均值は ほぼ正常值内であったが，不変例では改善例の 2 倍以上 の高値を示し経過した，BS は改善例，不変例ともMO80 投与 6 時間で最高値を示し，不変例で若干高値であっ た.IRI (Fig. 1) は改善例，不変例とむ MO-80投与 6 時間で最高値を示すが, 改善例は不変例に比し約 2 倍の 高値で変動した。

IRI/IRG モル比の変動と昏睡度の推移を Fig. 2 に示 した. 不変の症例10では IRI/IRG モル比の上昇はみら れず, 改善の症例 3，4，6，7ではこの比は MO-80 

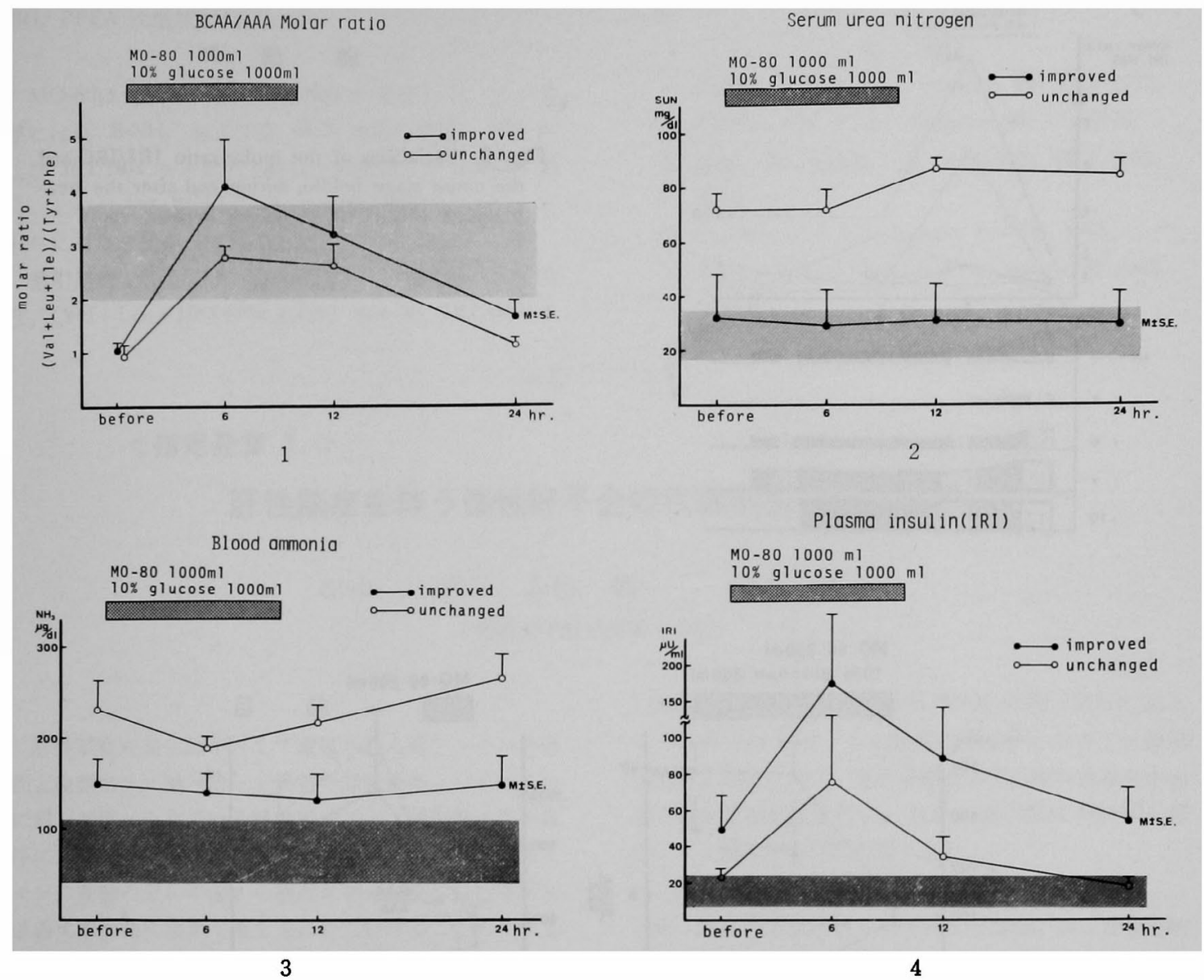

Fig. 1 Variations of the chemistries before, during and after the treatment of MO- 80 in socondary hepatic coma

投与䄪 6 時間で上昇し，とくに孯睡度の改善の著しい症 例 3，4で著明であった。 PFFA は遊離の Trp との関 連で注目される゙が，改善例では MO-80投与6時間で 隇少がみらた。

2）MO-80連日 1 週間投与例: 5 例中 4 例で BCAA/ AAA モル比の改善がみられず，うち3 例は昏睡が改善 したが, これらの症例では高 $\mathrm{NH}_{3}$ 血症の改善がみられ た。

\section{2. 㽖物実駼}

MO-80 単独ならびに glucose 併用投与群とも Fig. 3 の如く，投与中 BCAA は增加， AAA は減少し，BCAA/ AAA モル比は上昇した. とくに glucose 併用群は単独 群に比し AAA の減少は著明で有意であった。IRI は単
独群では不変, glucose 併用群では BCAA/AAA モル比 と平行して BS とともに増加した。

エック瘦犬に MO-80 と筋弛緩昘州との同時投与を行な うと，筋弛緩により Val, Leu, Ile が著しく血漿で増 加したが，筋弛緩剤単独投与ではこの傾向はみられな w.

ェック瘦犬でインスリン投与中 BCAA/AAA モル比の 低下 (BCAA, AAA は共に減少, BCAA の減少著明), BS の減少, IRG の增加がみられた. インスリン中止後 glucose を静注すると BCAA の著明な增加をみ, BCAA/ AAA モル比が上昇し, IRG, PFFA が減少した。エッ ク瘦犬でグルカゴン投与中 BCAA/AAA モル比は軽度に 上昇 (BCAA, AAA は共に減少, AAA の減少著明) し, 


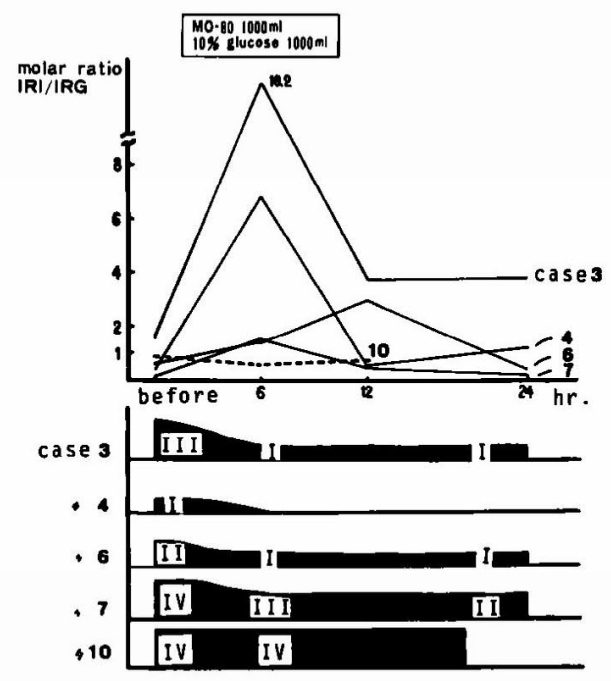

Fig. 2 Variations of the molar ratio IRI/IRG and the coma stage before, during and after the treatment of MO-80 in secondary hepatic coma
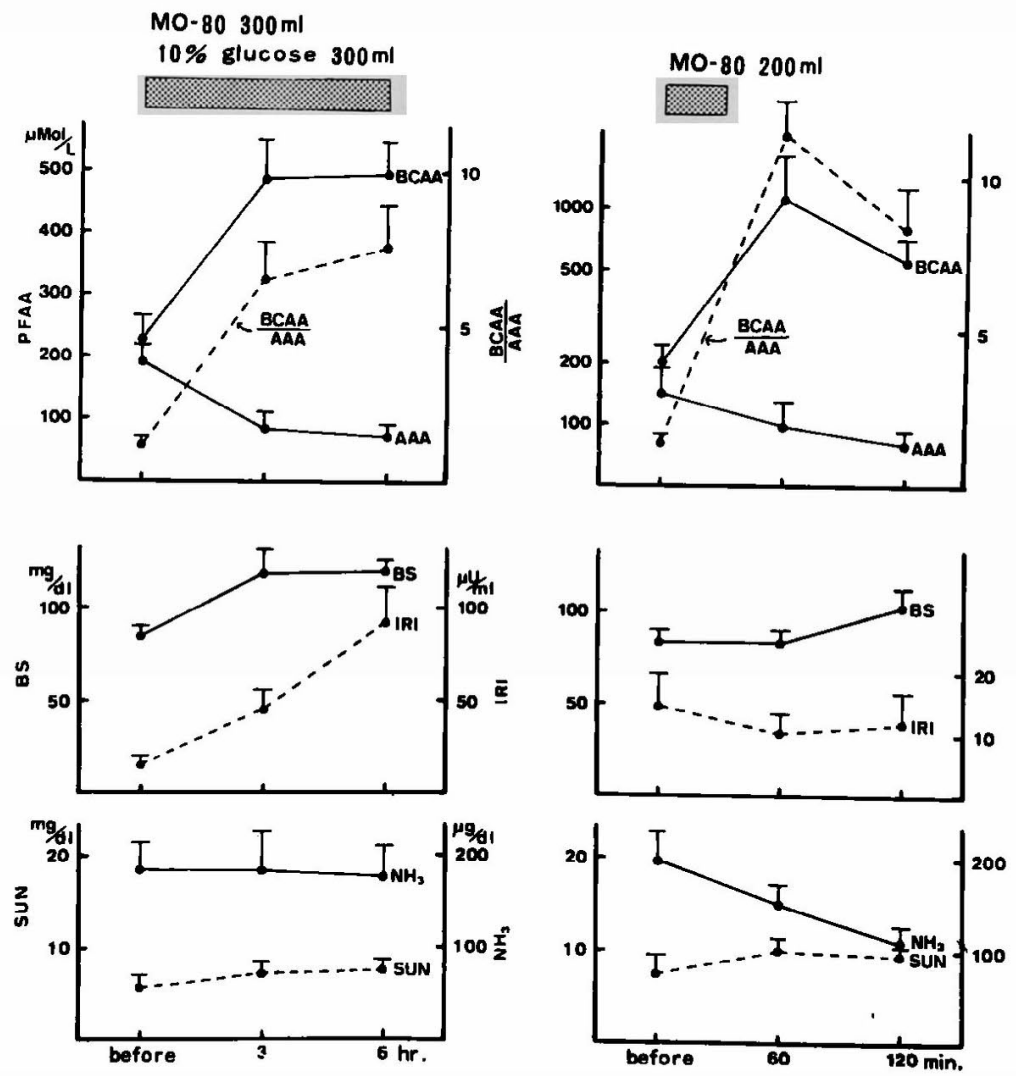

Fig. 3 Variations of the chemistries before, during and after the treatment of MO-80 in Eck fistula dogs 
IRI, PFFA 憎加した。

IV. 結 論

MO-80は glucose との併用療法が望ましく，その効 果には高 B-NH: 拉よび高 SUN 血症の改善, IRI お よび IRI/IRG モル比の上昇などの諸因子が有効性に働 く. したがって BCAA/AAA モル比の改善ととむに, こ れらに対する配虑が重要である。

索引用語 : 肝性昏睡, 特殊組成アミノ酸 $(\mathrm{MO}-80)$ 療 法, $($ Val+Leu+Ile)/(Phe+Tyr) モル比, IRI/IRG モ

ル比

文献

1) Fischer, J.E. et al.: Surgery, 78: 276, 1975.

2) Fischer, J.E. et al.: Surgery, 80: 77, 1976.

3) 海藤 勇, 佐藤俊一他：日内会誌, 67 : 1103 , 1978.

4) Curzon, G. et al.: Lancet, I: 1092, 1975.

5) Soeters, P.B. \& Fischer, J.E.: Lancet, II: 880, 1976.

\title{
<指定発言 1.>
}

\section{肝性脳症を伴う慢性肝不全の代謝動態とその対策}

\author{
田中 昭 赤松 與一 相原 廣子 \\ （愛缓大学医学部第 3 内科）
}

\section{目的}

仠珄脳症の発生因子として重視される高アンモニア血 症と血獎アミノ酸パターン異常の発現機序，およびこれ に対して用いられている特殊組成アミ，酸製剂の作用㙨 序について，アミノ酸，フンモニアおよび関連したホル モンの変動の分析の面から検討を加古, 更に肝性脳症を 改善すると共に窒素平衡を正にかたさけることのできる アミノ酸供給の量と方法について検討した。

\section{方 法}

当院入院の症例について，1）肝硬変22例（慆症 6 ,

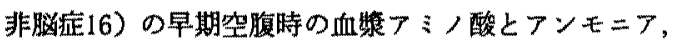
これらの代飶と関係㳭い insulin, glucagon 怙よび血糖 を測定し，これらおよび肝機能検査成績の相互関係を検 討した．2）脳症 3 例，非脳症14例の肝硬変に，分岐鎖 フミノ酸の多く配合された特殊組成フミノ酸(GO-80) $40 \mathrm{~g}$ を経静脈的に投与し，前記各項目について，GO-

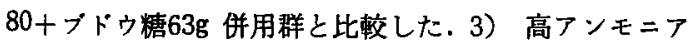
血症を伴った 4 例の肝不全例に，食触蛋白量を 1 日（a）
$1.5 \mathrm{~g} / \mathrm{kg}$ ，(b) $0.8 \mathrm{~g} / \mathrm{kg} ＼mathrm{~ （ c ） ~} 0.8 \mathrm{~g} / \mathrm{kg}$ の経口掑取に加え て GO-80又は綜合フミノ酸剤の形で40g のアミノ酸投 与を各 2 週間行った. 更に昏睡患者には経口摂取を中止 して完全静脈栄飺を行い, 且つ, 蛋白質は GO-80 と棕 命アミノ酸の形で72g を投与した。

\section{成結 と結論}

1) 脳症例では血嶈アンモニアの高值と共に血獎分岐 鎖フミノ酸の芳香族アミノ酸に対する比 (BCAA/AAA) の低下が著明であった，2）慢性朋不全では，その程度 の強いわの活 BCAA/AAA もインスリン・グルカゴ

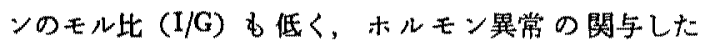
catabolic state であることがらかがわれだ，3） GO-80 単独投与では BCAA/AAA の上昇がみられるが，GO-80 とブドウ糖併用投与では BCAA/AAA と共に I/G の上 昇がみられた，4）高アンモニア血症を伴ら慢性肝不全 患者に，経口蛋白摄取を制限し，不足蛋白量を経静脈的 にフミノ酸の形で補ら事により, 高フンモニア血症を改 善し窒素平衡も正にかたむけ得ることを明らかにした。 


\title{
4. 肝不全における血液脳関門の中性アミノ酸 輸送異常とその是正
}

\author{
渡辺明治 東 俊宏 長島 秀夫 \\ (岡山大学第 1 内科)
}

\section{I. 緒 言}

肝性脳症は肝不全にみられる全身の采統的代謝異常に 起因する重篤な合併症であり，とくに急性肝不全時の媨 浮腫とともに，その成因と対策の究明が重要視されてい $3^{1)}$. 劇症肝炎や肝硬変など肝不全症例やラットの劇症

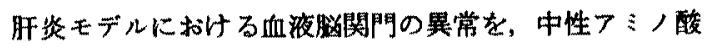
代謝動態の面から検討し，ホルモンやフミ／酸投与でて の是正を試みたので報告する。

\section{I. 方 法}

岡大第一内科に入院した劇症肝炎や肝硬変例などの䯣 液と血清のアミノ酸濃度を同時に測定した²．血清中性 フミノ酸湿度からそれぞれの髄液または脳内輸送速度 Vpre（理論的概算値, nmol/min/g) Michaelis-Menten

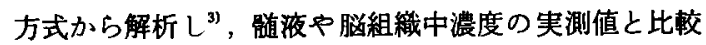
した. Sprague-Dawley 采ラットにD-ガラクトサミン (GalN，1.3g/kg 体重) t 1 回腹些内に投与し，24 48時間後に脳の水分量や $\mathrm{Na}^{+}$と $\mathrm{K}^{+}$濃度 ${ }^{4}$, 脳波 ${ }^{5)}$, 脳と血清のアミノクラムさらにVpre などを検討した。 ${ }^{14} \mathrm{C}$-Phenylalanine $\varepsilon{ }^{14} \mathrm{C}$-Leucine $の$ 脳内輸送系の $\mathrm{Km}$ $(\mu \mathrm{mol} / \mathrm{m} l)$ と $V \max (\mathrm{nmol} / \mathrm{g} / \mathrm{min})$ を脳取り込み率 (BUI，\%) から直接測定しだ．GaIN 投与12時間また は24時間後から，インスリンーダルカゴン (I-G), プレ ドニソロンと分枝鎖 アミ，酸製剤 Hep-OU ${ }^{22}$ を体重 $109 \mathrm{~g}$ 当り $0.2 \mathrm{U}-0.2 \mathrm{mg}, 1 \mathrm{mg}, 140 \mathrm{mg}$, それぞれ12時間 または24時間に 4 回投与し（水分投与量は $2.5 \mathrm{~m} l / 100 \mathrm{~g}$ 体重)，上記の各指標に及ぼす影響を観察し，それらの 臨床治療的意義について検討した。

\section{III. 成 縤}

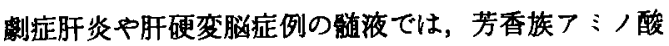
と Methionine 涱度が著しく增加し, 血清澧度の31〜77 \%に達した。性了ミノ酸のVpre むこれらアミノ酸で 增加を示し，対照例と異なって㗓液濃度の実測值との間 に著しい解離がらら，血液脳関門での中性フミノ酸運 搬体系機能の異常が示唆された (Fig. 1)。むたHep-OU

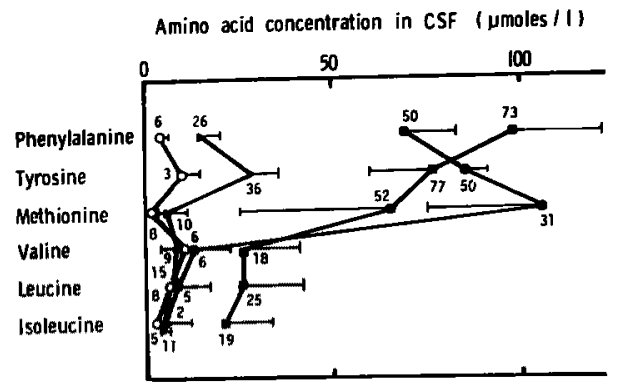

Fig. 1 Concentrations of neutral amino acids in cerebrospinal fluid (CSF) and their CSF/serum concentration ratios in control subjects and patients with fulminant hepatitis and liver cirrhosis. Serum and CSF neutral amino acids were simultaneously determined by liquid chromatography with a Nihon-Denshi JLC-6AH amino acid analyzer. Control (No. of patients studied $=6$ ) $0-O$, fulminant hepatitis (5) -0, liver cirrhosis with coma (4) $\mathbf{\square}-\mathbf{a}$ and liver cirrhosis without coma (5) $\Delta-\Delta$. Numbers indicate average values $(\%)$ of $\mathrm{CSF} /$ serum amino acid concentration. Horizontal bars show standard error (S.E.) of the mean.

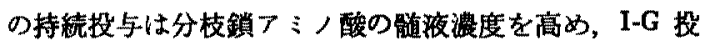
与とともに肝性脳症を觉醒させた. GalN 投与24時間 後, 脳浮宱, 高振幅徐波や三相波など脳波異常の出現と Thrombotest や血清コレステロール值の著減などがみ られた (Table 1). また中性アミノ酸のVpre とこれら 脳内実測值との相違は, 芳香族 と分枝鎖】ミノ酸で明らかであった. I-Gゃ Hep-OU 投与は，GalN 投与ラットの脳波 (48時間後) と脳 PhenylaJanine と Methionine 濃度の異常（24時間後）を 改善したが (Fig. 2), プレドニンロンの影警は明らか でなかった，GalN 投与に上る急性肝不全ラットで求め た Phenylalanine と Leucine $の$ 脳内輸送系の $\mathrm{Km}$ と

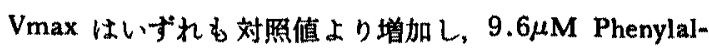


Table 1. Physiochemical alterations of blood and brain in galactosamine-treated rats. Male Sprague-Dawley rats were starved overnight. Galactosamine was administered intraperitoneally as a neutral solution in a single dose of $130 \mathrm{mg} / 100 \mathrm{~g}$ body weight. Rats were given only water ad libitum and sacrificed 24 or $48(\$)$ after galactosamine injection. Control animals were similarly treated after receiving saline injection. Brain dry weight and electrolytes were measured in samples taken from cortical area as previously reported (Reference No. 4). Three rats were studied in each group. Data are presented as the mean \pm S.E. and were analyzed by Student's $t$-test. * $\mathrm{p}<0.05$ compared to control values.

\begin{tabular}{c|c|c|c|c|c}
\hline \multirow{2}{*}{ Treatment } & \multicolumn{3}{|c|}{ Blood } & \multicolumn{2}{c}{ Brain* } \\
\cline { 2 - 5 } & GPT (IU) & $\begin{array}{c}\text { Cholesterol } \\
(\mathrm{mg} / \mathrm{d} l)\end{array}$ & $\begin{array}{c}\text { Thrombotest } \\
(\%)\end{array}$ & $\begin{array}{c}\text { Dry weight } \\
(\%)\end{array}$ & $\mathrm{Na}^{+} / \mathrm{K}^{+}$ \\
\hline Control & $23 \pm 4$ & $90 \pm 4$ & $107 \pm 1$ & $23.0 \pm 0.3$ & $0.44 \pm 0.01$ \\
GalN & $2200 \pm 522^{*}$ & $46 \pm 9^{*}$ & $56 \pm 15^{*}$ & $21.0 \pm 0.9$ & $0.54 \pm 0.02^{*}$ \\
\hline
\end{tabular}

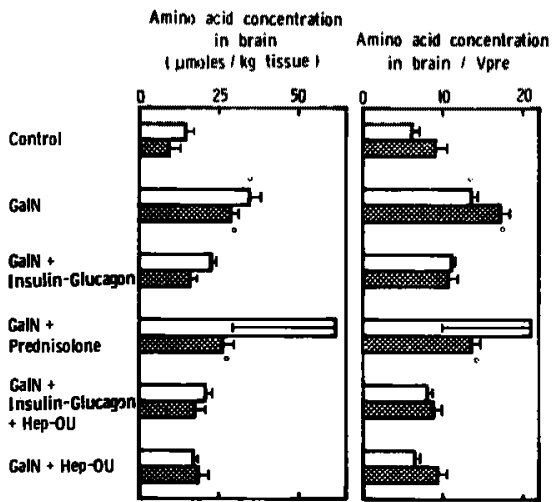

FIg. 2 Effect of insulin-glucagon, prednisolone and Hep-OU on brain phenylalanine and methionine concentrations and their transports across the blood-brain barrier. Insulin-glucagon, prednisolone and Hep-OH were intraperitoneally injected four times at a 3 hours' interval from 12 to 24 hours after galactosamine administration at a total dose of $0.2 \mathrm{U}-0.2 \mathrm{mg}, 1 \mathrm{mg}$ and $140 \mathrm{mg} / 100 \mathrm{~g}$ body weight, respectively. The injections were carried out in a total volume of $2.5 \mathrm{ml} 5 \%$ glucose $/ 100 \mathrm{~g}$ body weight. Numbers of rats studied were 3 in all experimental groups. Vpre ( $\mathrm{nmol}$ $\mathrm{min}^{-1} \mathrm{~g}^{-1}$ ) of neutral amino acids were calculated from serum neutral amino acid concentrations according to the equation of Pardridge(Reference No. 3). Horizontal bars indicate S.E. of the mean. ${ }^{*} \mathrm{p}<0.05$ compared to control values. Phenylalanine, $\square$ and methionine, $\square$.

anine の BUI は I-G 投与で減少し, Hep-OU との併 用は一層好果的であった。

\section{IV. 考 案}

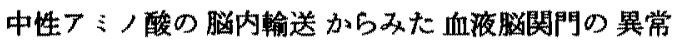
が, 肝不全時の肝性䐆症，脳波異常や脑浮腫の発症と相 互にどのように関連しているかは重要な問題である. 正 常の肝機能に依存する脸生理機能が肝不全に伴ら代謝異 常によって変化し, 血液脳関門での中性てミノ酸輸送異 常が萩起され, 芳香族アミノ酸や Methionine の血液か らの㨫内流入を增大させ, cytotoxic edema を一層助長 して，非可这的な脳障害へと進展するものと理解され る.従って, 肝性脳症に対する治療法をどのような病期 にどのように開始するかが臨床的に重要で，そのために は肝不全時の神経学的変化や脳波所見の特徵を一層明確 に分析し，その目安を得るよら神経学-肝臓学の共同研 究が望まれる.

\section{V. 䊅 語}

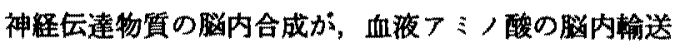
機䊦により調節されており，肝不全にみられる血液脳関 門の異常が肝性譄症を誘発する可能性が示唆された. I-G または Hep-OU との併用投与が肝不全時の脳内中 性アミノ酸輸送の偏倚を是正したが，その作用機序の詳 細, とくに血液脳関門でのアミノ酸運搬体系のホルモン 調節についてはさらに多くの実験的検討を必要とする。

索引用語 : 肝不全, 血液脳関門, 中性アミノ酸, イ ソスリンータルカゴン, Hep-OU

$$
\text { 文献 }
$$

1) Ware, A.J., D'Agostino, A.N. et al.: Cerebral edema: A major complication of massive hepatic necrosis. Gastroenterol., 61: 877, 1971.

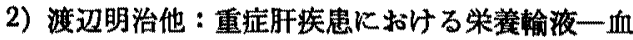


清アミノ酸澧度の不均衡是正を中心にして。肝 践, $20: 28,1979$.

3) Pardridge, W.N.: Kinetics of competitive inhibition of neutral amino acid transport across the blood-brain barrier. J. Neurochem., 28: 103, 1977.

4) Zimmermann, V. \& Hossmann, K.-A.: Re- suscitation of the monkey brain after one hour's complete ischemia. II. Brain water and electrolytes. Brain Res., 85: 1, 1975.

5) Livingstone, A.S. et al.: Changes in the blood-brain barrier in hepatic coma after hepatectomy in the rat. Gastroenterol., 73: 697, 1977.

\title{
5. 重症肝障害におけるアミノ酸代謝異常とその対策
}

\author{
川出 靖彦 武藤 泰敏 \\ （岐鼻大学第 1 内科）
}

重症肝障害においては，肝ならびに末梢組織でのアミ ノ酸代謝動態に重大な变化がるたらされる.我々は，特 に肝性脑症発現と，体内了ミ>酸代謝異常，さらに脳症 改善に扣よぼす分枝鎖フミノ酸 (BCAA) の影響を中心 に膎内モノフミン動態との関係から検討した。

\section{对象およひ方法}

肝硬変脳症例ならびに劇症肝炎例を対象とした。

全血了ミ八酸は早朝空腹時大腿動静脈よりへパリン採 血し，等量の蒸留水を加え溶血した後，1\%ピクリン 酸で除蛋白，日立 KLA 5 型自動フミ，酧分析器にて 测定. 脳春道淮 (CSF) は腰椎穿刺により採取した。 血獎総 Trp, CSF ・ Trp は11.25\%過塩素酸で除蛋白後 Denckla-Dewey 变法に準じ溂定, 遊離型 (フルブミン 非結合型) Trp はダイヤフローメンブレン PM 10を用 い，加压限外娍過後測定した.

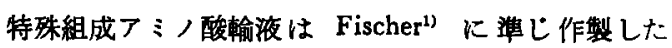
GO-80-I と, BCAA のみを GO-80-I と同等量含有する GO-80 III 作製")，これらの $500 \mathrm{ml}$ を単独で 2 時間か け静脈内投与し，昏睡度の経時的変化を観察した。

\section{結果}

非代償性肝硬変症例の大臥動静脈全血 差でみた末梢組織フミノ酸ネットバランスは，正常対照 群に比し Tyr, Phe の放出增, BCAA, Ala の放出減少傾 向を示し，脳症例ではその㑯向はさらに增強し，BCAA の末梢組䋐からの放出がまったくみられなくなる例す認 められた。フンモニアの末梢組織への取込みる有意に增

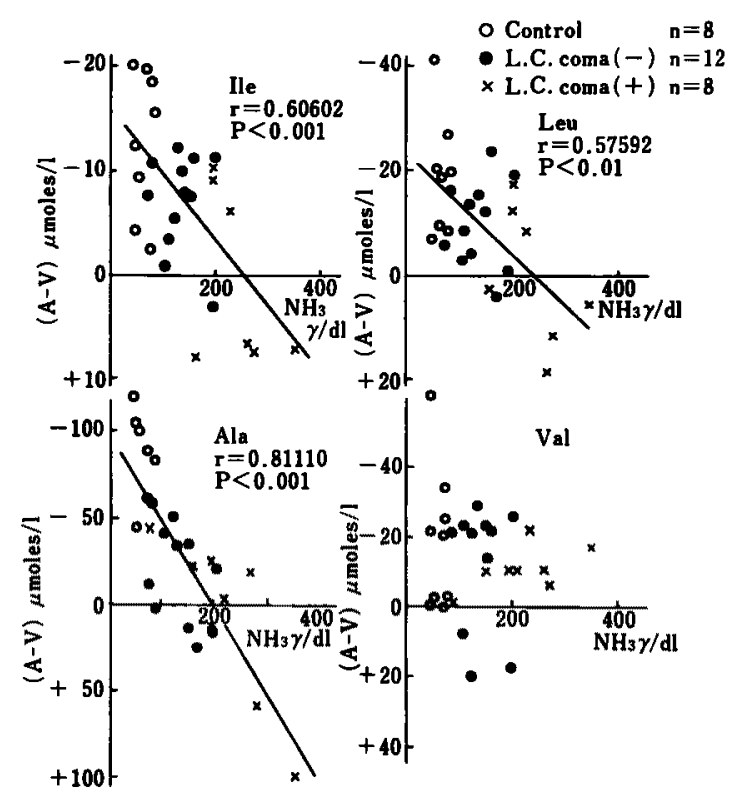

Fig. 1 Correlations between arterial $\mathrm{NH}_{3}$ concentration and femoral arterio venous differences of isoleucine, leucine and alanine.

加していた．動脈血アンモニフ濃度と大腿動静脈全血ア ミノ酸浱度較差との相関をみると, Ile, Leu, Ala にお いて有意の相関がみられた（Fig. 1).

血㢡釉 Trp は正常対照群 $19.8 \pm 1.9(\mu \mathrm{g} / \mathrm{m} l)$ K対 , 肝硬変脳症例18.6土4.4と有意差は認められれいが，遊 
離型 $\operatorname{Trp}$ (フルブミン非結合型) は正常1.9土0.6, 非代 暴性肝硬恔症 $5.1 \pm 2.8$, 脳症例 $6.4 \pm 2.3$ と正常対照群飞 比し有意に增加していた。

CSF TrP は对照群0.7 \pm 0.1 K対し, 肝硬变非脳症例 $1.7 \pm 0.8$, 脳症例 $3.2 \pm 1.3$ と有意に增加していた。血策 と CSF を同時に採取した26例の血獎遊離 Trp と CSF Trp をみると，非脳症例，脳症例いずれる有意の相関が 認められた (Fig. 2). しかし, 腷症例の CSF Trp は,

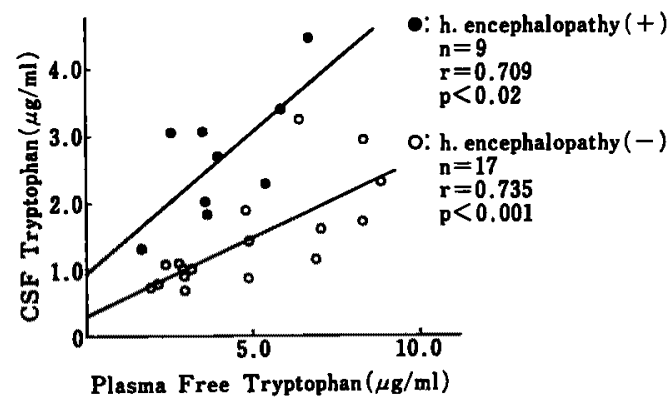

Fig. 2 Correlation between plasma free (albuminunbound) tryptophan and cerebrospinal fluid tryptophan in liver diseases with or without encephalopathy.

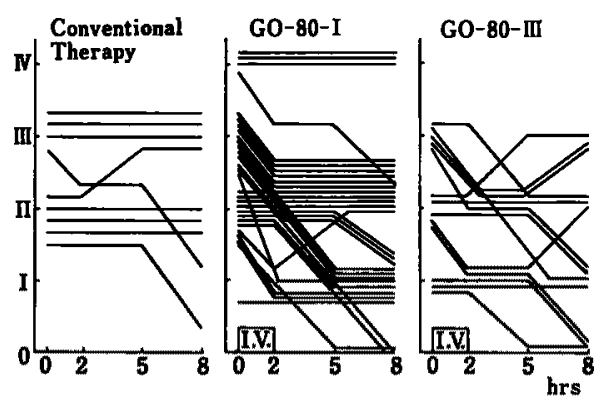

Fig. 3 Effects of GO-80 infusion on coma grades in patients with hepatic encephalopathy.

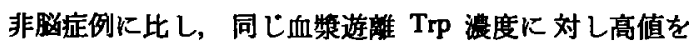
とっており，脳症時においては，血中 Trp の脸内進入 がえ進していると推測された。

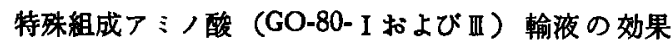
(Fig. 3) は，図左の Lactulose，抗生剂，グルタミン 酸ソーダ等に上る従来の肝性嵒症治療法と比較 L, 効 果発現は速効的であり，投与終了直後の 2 時間後には GO-80 I 59\%，GO-80 II 46\%の 改善率を 示し，8 時間後 に怯，GO-80 Iは，69\%が治療前より改善していた。
GO-80 III効果の持繶は短い㑯向にあるが，投与直後 の脳应改善效果は，GO-80 I とはぼ同様であった，即 ち，GO-80 I 怙よび共通する成分である BCAAの 投与が，脳症改善の中心的役割をむつとみなされる。

GO-80投与による脳内了ミ，酸瀑度を急性虚血性肝不 全ラットでみると, 投与後 BCAA 濃度の增加, Met Phe, Tyr, Trp の減少を認め, 特に GO-80 III投与では, Phe, Trp は正常対照群と同じ瀑度にまで減少した。

\section{考 案}

重症肝障害時にみられるPhe, Tyr, Trp の增加は, これらフミノ酸か脳内モノフミン即ちカテコールアミン やセロトニンの前駆体であることから，脳症発現機序と

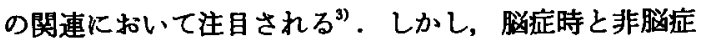
時の血䈋遊嵟了ミノ酸濃度で差がみられるのは BCAA のみであり，Phe，Tyr，Trp には差がみられず，むし

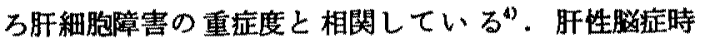
BCAA は Goldberg の説》，我ヶの成績からみて， 末梢組織ことに筋でのアンモニア処理に利用されてい ることが推測される。しかしこの脳应時にみられる BCAA の減少は，脳内てミノ酸との関連で注目すべきで あろ5. 即ち脳血液関門を通り脑内へアミノ酸が進入す る時, 中性了ミ /酸 (BCAA, Phe, Tyr, Trp, Met 等) は互に競合することが知られておうり，血中 BCAA の減 少は，脳内へ他の中性フミノ酸の進入增加をるたらすと 考えられる. CSF Trp が非脳症時に比し脳症時高值で あったことは，この中性アミノ酸相互の競合の結果と理 解してむよいであろ5．GO-80投与の脳应改善効果も血 中 BCAA の增加に上り䏚内 Trp, Phe, Tyr の浱度を減 少させ, その結果脳内セロトニン代謝が正常化すること が一因であるう。

索引用語：肝性脳症，フミノ酸（血墏遊離），トリ プトファン(血雅遊離一), トリブトファン（蹃液一）.

\section{文献}

1) Fischer, J.E. et al.: Surgery, 78: 276, 1975.

2）天野和雄：岐阜紀要，27:131，1979.

3) Fischer, J.E. and Baldessarini, R.J.: Lancet, II: $75,1971$.

4) 松井園生：岐阜紀要， $27: 99,1979$.

5) Goldberg, A.L. and Chang, T.W.: Fed. Proc., 37: 2301, 1978. 


\section{6. 急性肝不全時の血漿アミノ酸パターン の変動に関する実験的研究 一肝全摘術後の血漿アミノ酸パターンの変動一}

高浜 龍彦杉浦 光雄 和田 達雄 (東京大学第 2 外科)

急性肝不全時に血潩アミノ酸濃度の上昇する機序につ いては, 壊死肝組織から遊離されるのか, 或は肝機能の 脱落による代謝の異常化に基くのかを含めて，未解明の ことが多いここの急性肝不全時の血㢡了ミノ酸パターン の珙常变動の機序を知る上で, 肝全摘術後の無肝笑験動

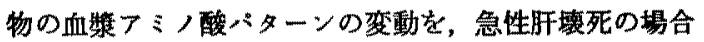
の变動と比较検討することは有用な方法である。

\section{研究方法}

$12 \sim 17 \mathrm{~kg} の$ 雑種成犬20頭にネンブタール麻酔下，門 脈と下大静脈の間に側々吻合で，ECK 瘦を造設した後， 肝を一塊として摘出, 肝部下大静脈を Gore-Tex 人工血 管で置換するといら方法で肝全摘術を施行した。術中, 術後は，RINGER 液と $5 \%$ ブドウ糖の 輸夜を行い，輸 血は行っていない，訹前と術後 3 時間毎に経時的に採血 を行い，一般生化学検查と血獎了ミノ酸分析を施行し た.フミノ酸分析は, 採血後值ちに4000回転10分間遠沈 し, sulfosalicylic acid 粉末 $250 \mathrm{mg}$ を加文て除蛋白後, 凍結 し，12時間内に，日立 KLA- 5 型 autoanalyzer を用 いてクェン酸ナトリウム法によるカラムクロマトクラフ 1ーにて行った。

\section{結果}

各遊離アミノ酸の濃度を術前を $100 \%$ に換算して，術 前及び術後 3 時間， 6 時間， 9 時間，24時間での経時的 変動として検討した。

血漿中遊離了ミ/酸総量は，術後 3 時間で既に有意に 上昇を示し，その後も上昇を続け 術後24時間で術前の 4.5倍に達した.

essential のフミノ酸のらち, Threonine, Phenylalanine, Lysine は, 街後 3 時間で既に有意の上昇を示し, その後す上昇を続け，術後24時間で，各々6.5倍, 11.5 倍，6.7倍に達した。これに対して，Valine, Leucine， Isoleucine の側鎖アミノ酸 3 種は, 軽度の減少を示し, Tryptophan は術後 6 時間では術前の54\%と有意な減少

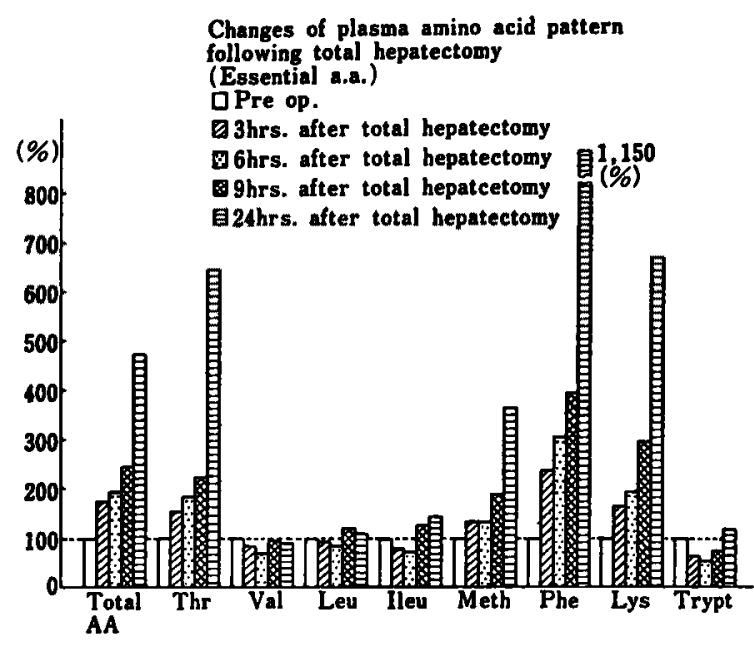

FIE. 1

を示し, 術後24時間です術前の1.1倍に留まった. Methionine る，術後 3 時間で術前の130\%を示し，術後 9 時間までは軽度の上䄯に留まり，統計学的には有意の上 䒜とは言党なかった。

non-essential $の 7 ミ$ ク酸である, Taurine, Asparate, Glutamine, Serine, Proine, Glycine, Alanine, Tyrosine, Ornitine, Histidine, Arginine の11種のアミノ酸につい て，同様に経時的変動を検討した。これらのアミノ酸 は，いずれも術後 3 時間目から，有意の上昇を示し，そ の後む急速に上昇を続け，Tyrosine に执いては術後24 時間で，術前の10.7倍に達したか;，Alanine のみは，術 後 3 時間での上昇が他のてミ，酸に比して最む著明で， その後はあまり変化しないという点で, やや異なった推 移を示した。

側鎖アミノ酸と芳香族了ミノ酸の比(Leu+Val+Ileu/ Phe+Try) は，術前値4.3から，術後 3 時間で1.71，9 時間で1.15，24時間で0.48へと变動した。 


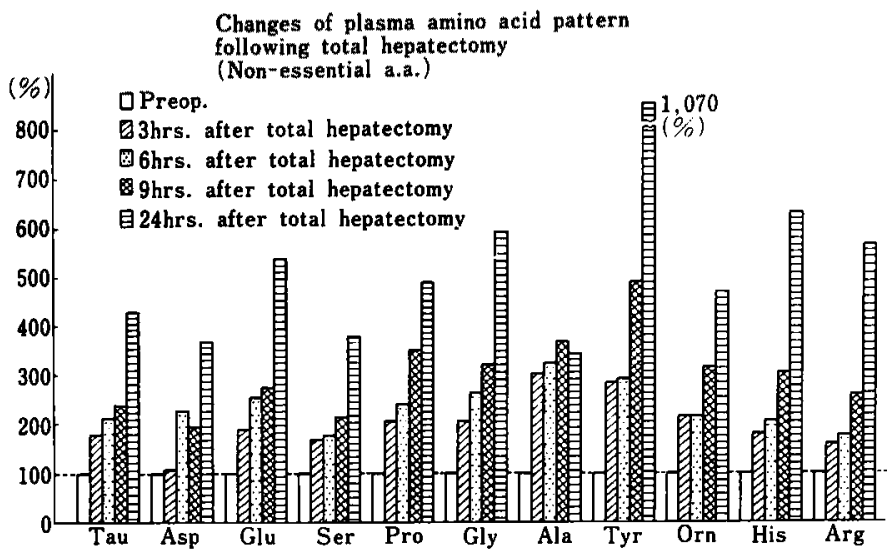

Fig. 2

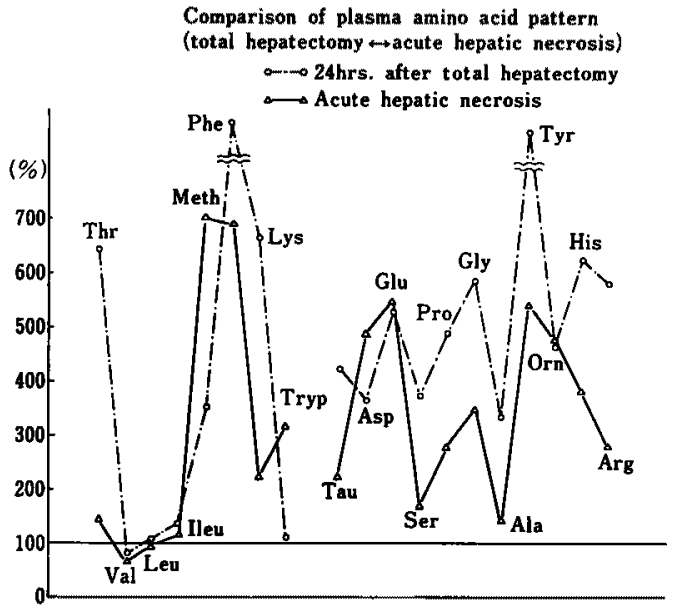

Fig. 3

この肝全摘術後の租獎アミ，酸濃度の变動が如何なる 機序によるるのかをより明らかにするため，壊死肝組織 を含む急性肝壊死の場合の血漿フミノ酸パターンと対比 して検討を行った. 肝全摘後24時間の血獎つミノ酸のパ ターンと, 肝性脳症を伴う激症肝炎の臨床例での血永て ミノ酸パターン (Harveyによる) を比較検討した。両 者共によく似たバターンを示しているが，肝全摘群の方 では, Tryptophan の上昇がみられないこと, Methionine の上昇が軽钘であること，Threonine の上昇が著明なこ とが主たる相違点として認められた。

\section{結論}

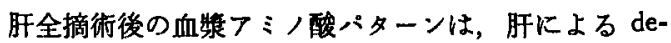
amination 作用の脱落のため，苊雷族つ、，酸の上昇，
側鎖フミ，酸の低下等，急性肝薯死の場合しよく似だ゙ ターンを示すが，次の二，三の点で相違を諗めた。

1) Alanine の增加が早期から高值を示すこと，2） Methionine の増加が軽微であること，3）Tryptophan は増加せず，むしろ減少する㑯向にあること．

この差異は, 肝全摘後の血漿アミノ酸の変動には, 肝 の代謝能の完全脱落のみで，壊死肝組織の及ぼす因子が 作用しないといら差に基くものと考えられる. 従って, 通常の肝壊死を伴う急性肝不全の場合に認められる血獎 中 Tryptophan, Methionine の上昇は, 肝壊死組織に由 来するものと考えられる．また，肝性昏睡には，血獎中 遊離 Tryptophan の上昇は必ずしす相伴わないと考えら れる.

素引用語：肝全摘，（Gore-Tex一）人工血管，急性 肝不全，(血獎一）丁ミ，酸（パーン）

$$
\text { 女 献 }
$$

1) Harvey, M.R. et al.: Plasma amino acid patterns in hepatic encephalopathy of different etiology. Gastroenterology, 72: 483-487, 1977.

2) Record, C.O.: Plasma and brain amino acids in fluminent hepatic failure and their relationship to hepatic encephalopathy. Europ. J. Clin. Invest., 6: 387-394, 1976.

3) Aguirre, A.: Plasma amino acids in dogs with two experimental forms of liver damage. J. Surg. Res., 16: 339-345, 1974.

4) Fischer, J.E. et al.: Plasma amino acids in patients with hepatic encephalopathy. Am. J. 
Surg., 127: 40-47, 1974.

5) Fischer, J.E.: The effect of normalizatiofn of plasma amino acids on hepatic encephalopathy. Surgery, 80(1): 77-91, 1976.

\title{
<指定発言 2. >
}

Polyacrylonitrile membrane を用いた人工肝補助 装置による劇症肝炎の治療

一アミノ酸除去能を中心に一

\author{
酒井一也 \\ （信楽園病院内科） \\ 佐々木 博 \\ (富山医科桼科大学第 3 内科) \\ 市田 文弘 \\ （新眮大学第 3 内科）
}

我々は1977年以来現在迄に 9 例の钊症肝炎患者に polyacrylonitrile membrane (以下 PAN 膜之略す) を用 いた人工肝補助装置による治寮を行ない，4 例に意識の 回復をみ，らち2 例を救命し得た。今回は本法により劇 症肝炎のアミノ酸代謝巽常がどの程度改善されるかを検 討し以下の成箐を得た。人工肝補助装置の施行方法は PAN 膜透析法（以下 PHD） 6 回，PAN 膜透析濾過法 (以下 PHDF) 20回, PAN 膜滤過法 (以下 PHF) 8 回の計34回である.（1）劇庭肝炎では Methionine, Tyrosine, Phenylalanine 等のてミ八酸の上昇が氵 総てミノ酸量す增加しているが, Valine, Isoleucine, Leucine は減少する．意識を回復せずに死亡した例と意 識回復例では, 治寮開始前のアミノ酸値は後者が低值を 示した.（2） PHDF の施行前後でみると Methionine $49 \%$, Tyrosine $44.3 \%$, Phenylalanine $38.4 \%$, Valine $22.8 \%$, Isoleucine $40.8 \%$, Leucine $21.9 \%$ 隇少率で あり, PHDF の透析器の前後ではそれぞれ38.3\%, 32.3
$\%, 31.7 \%, 36.4 \%, 30.6 \%, 30.9 \%$ 減少率であっ た. 他法と比較すると総了ミ，酸量の減少率は PHDF の施行前後で $45.9 \%$ と最高く, PHD, PHF, charcoal を用いた装眉の施行前後では約30\%であったが，交換輸 血では13.3\%であった。各アミノ酸の減少率む交換輸血 療法に比べて高値で, 特に PHDF でその傾向が強か った.（3） Val+Leu+Ileu/Phe+Tyr の比は治潦前, 明らかに低值を示したが，PAN 膜を用いた装固でも charcoal を用いた装登です，又交換輸血によってもその 施行後に改善をみなかった（4）透析液と湖過液中に 排泄されたフミノ酸量を検討すると，PHDF の終了時 には, 1 回に約 $10 l$ の体液固換を行なった例では約 $10 \mathrm{~g}$ の，50l の体液值換を行なった例では30〜40g のアミ， 酸の排泄がみられた。血獎総了ミ，酸量が $200 \mathrm{mg} / \mathrm{d} l$ を 越える高佔を示した症例の PHF の終了時の淐過液中に

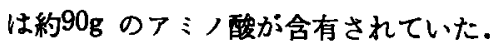




\title{
<特別発言 $>$
}

織田 敏次

（東京大学第 1 内科）

肝不全の病態生理を中心に，最近の話題を討論いただ いたわけたが，まず感じられるのは，「歴史は綝返す」 の実感である．それでいて决して昔のまま止まることを 知らない.

肝細胞の再生を促そうとするインシュリン・グルカュ゙ ン，分枝鎖アミノ酸と肝性昏睡の関係を導いた Eckの fistel, いずれもその厢史は決して新しいものではない. そのような過去を土台にしてこそ，また新しい概念な

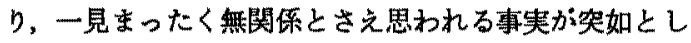
て生みだされてくる.土台になった基礎の事奉がそるそ ろまったく忘れ去られたかに思われる頃に，である．不 連続む連続の上にこそ成りたつ。

インシュリンが肝硬変の治療に用いられたのは, われ われ現代の人間は知らない，しかし肝障害には蛋白が有 害と考えられていた時代がかなり長い間続いた頃，クル コースと一緒に使われた一時代があった。 ラットルイン シュリンをあたえると，肝の ATP は増してくれる.こ のことは演者す確かめることができていた．しかし，イ
ンシュリンは筋により強く働くために, 次第に忘れ去ら れていった。

アミノ酸がペーパー・クロマトグラフィー法によって 測定され始めた頃，芦沢現東京医大教授ととあにこれを 検討して，血中の芳香族てミノ酸が肝不全時に増量する ことはすでに確かめていた．しかし，いかんせん分枝 鎖つミノ酸までは見る目を持たなかった。昔ながらの Eck 䘫に立ち戻ること火よって初めて，見出される心 メとはなった。

契験条件はより単純なるのでなければならない、とあ らためて知らされるのである。

昨今はさらに人工肝膈が話題になっている，単なる透 析, 濾過のみでは果たされ得ない面が残されている.肝 不全因子を追究するとともに，肝のもつ代謝機能をぜひ とる組み込む必要性を感じている.ある程度の試行錯誤 はやひを得まいが，これす歴史のらえにたってこそかな えられる期待なのではあろら。

\section{<特別発言>}

\author{
暮西 洋一 \\ (北海道大学第 1 外科)
}

本シンポジウムでは，肝不全における代謝動態とその 対策について，アミノ酸の面から検討した研究が主体と なった．教室での知見を追加して私見を述へたい．

雜種成犬を用い，胃十二指腸動脈結禁切離と門脈下大 静脈吻合を行うと共に総肝動脈に閉塞子をおき，これに より48時間後に 無麻醉下に 体外から 総肝動脈を閉塞す る. 対照群 ( 4 頭) では榶液補給法のみを行ら.治療群 ( 3 頭) では更に，総肝動脈閉塞の 2 時間後よりPAN 膜による ultrafiltrate を XAD-4 Resin で潅流した後，

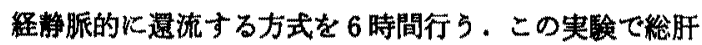

動脈閉塞後の平均および最長生存時間は, 対照群で13, 16時間, 治療群で19，29時間であった. SGPT とSGOT は治療群では対照群よりも低值であった．なお血小板減 少などの副作用もみとめなかった，対照群では，総てミ ノ酸の急激かつ継続的な上昇をみるが，これは治療群で は抑制された。

一方, 側鎖型てミノ酸の芳香族了ミノ酸および必須ア ミノ酸に対する比は，対照群で著しい低下をみたのに比 し，治療群では改善された．しかし正常域には回復しな thxot. 
肝不全の病態については，最近アミノ酸代謝がとくに 注目され，本日も討論されたごとく，各施設の結果も注 ぼ一致している、一方, 偽性神経伝達物質の肝性脳症原 因論に対する疑問む報告されて括り (Zieve)，その病因 解明には，上り多角的かつ系統的な検討か要求されてい るといえよう。

肝不全の対策については，フミノ酸㞠法の泳か，いわ ゆる Hepatic assist として各種の方法や装置が開発，
検討されているが，いずれも初期の目的を達していない と思われる。

旰不全の病因機序に不明の部分が多い現状では，その 対策孔異常代謝産物の除去と共に一時的にせよ肝の代謝 機能を代行するような方法としての肝組織の利用など， 多角的なアブローチによる方法が開発されなければなら ないと考える。

\section{司会者のまとめ}

\section{高橋善弥太菅原 克彦}

畈不全をめぐる問題は種々の領城にわたるか，今回の シンポでは，肝の再生と肝性譄症に関する問題が取り上 げられた.

肝の再生に関しては，血流，糖浿度，酸素，ミトコン ドリフ機能などの検討が必要なことが示され, 向肝性因 子として,インスリン，タルカゴンの問題が，取り上け゚ られた. インスリン, タルカゴン療法は, 再生肝やガラ クトサミン傷害肝について再生促進作用が報告されてい、 る. 然し，この両ホルモンには，糖代謝，脂肪酸代謝， サイクリックヌクレオチド関して相反的であり, 両ホ ルモンの投与の順序, 量的比率には, 更に多くの検討か～ 重赫られなければならず, 重要な研究課題として, 今後 の発展が期待される.

|肝性脳症の代謝動態ならびに対策としてはつミ/酸 の問題が浮妾㰹りにされ，慢性再発型の肝性昏睡には Fischer の処方による分枝フミノ酸の多い夜の輸夜か， 従来の療法よりはるかに優れた成績をあげることが,一 致して確認された．これは肝䑏病学の進歩の一つとして
特記すべきのである。それと同時に肝性昏睡には，少 なくとも二型を区別して取り扱らべきことが，この輸㬵 の効果,ならびに血漿了ミ/酸パターンの面からも再認 識された。

このフミノ酸パターンの異常, 及び治療効果の機序に ついては, インスリンリクルカゴン比の面から考察され たが，なお問題を残している．たた，末梢組織のフンモ 二ア処理と分枝了ミノ酸の分解が関連していることが示 されたことは注目されてよい，又，分枝了ミノ酸の有效 性が, Monro の仮説のごとく，脳内セロトニンの低下 を来すことによるのかといら点では，動物実験の成较も 示されたが，今後検討すべき重要事項である. 更にその 際 Monro の言う如く血墏総トリプトフォンが問題なの か，又は非結合性トリプトフンンが重要なのかといら間 題も肝性媵症の発現機序をめぐる課題として明らかにす る必要がある. 又, 脳浮腫発生機序についても今後を期 待したい。 